УДК 622.833

DOI: https://doi.org/10.26642/ten-2021-1(87)-155-162

С.Г. Негрій, к.т.н., доц.

ДВНЗ «Донецький національний технічний університет»

\title{
Вдосконалення методики вибору технологій охорони підготовчих виробок
}

\begin{abstract}
Розглянуто актуальність питання щуодо вдосконалення методологічних основ проєктування технологій охорони підготовчих виробок, особливо в умовах відпрацювання вугільних пластів на великих глибинах та у слабких бічних породах. Здійснено аналіз існуючих методик вибору технологій охорони підготовчих виробок. Встановлено, щэо ичии методиками регламентуються конкретні технології та обмежується можливість розгляду інноваційних рішень. Виключенням $\epsilon$ методика, щз запропонована у ДВНЗ ДонНТУ. Але вона потребує удосконалення з метою усунення на початковому етапі недоцільних технологій охорони виробок без проведення громіздких розрахунків за економічними критеріями. Тому метою дослідження стало вдосконалення методики вибору технологій охорони підготовчих виробок, яка б передбачала поетапний розгляд заходів щодо забезпечення експлуатаційного стану виробки та їх економічне порівняння. Запропоновано графічну інтерпретацію методики та ї̈ опис. Під час виконання окремих етапів методики аналізуються способи та засоби охорони виробок. Для иього може бути використано запропоновану класифікацію способів охорони підготовчих виробок, щзо передбачають вплив на навколишній масив, та рекомендаџї щчодо визначення конструктивних особливостей засобів охорони. Висунуто припущення, щุо отримані результати можуть бути підтрунтям для перевірки відповідності області використання та уточнення параметрів існуючих або розробки нових технологій охорони підготовчих виробок у складних гірничо-геологічних умовах.
\end{abstract}

Ключові слова: технологї охорони виробок; методика; пошук рішень; конструктивні особливості; слабкі породи.

Проблема та її зв'язок 3 науковими й практичними завданнями. Останнім часом під час підземного видобутку вугілля все більш актуальною стає проблема охорони гірничих виробок. Це пов'язано з ускладненням гірничо-геологічних умов відпрацювання вугільних пластів на великих глибинах [1-3] та в умовах слабких бічних порід [3-6]. Більшою мірою це стосується підготовчих виробок, які підтримуються позаду лави для повторного використання [7-9]. У таких умовах є необхідність правильного вибору технологій охорони виробок, застосування яких дозволить забезпечити їх ефективне підтримання. Зі зміною умов відпрацьовування вугільних пластів є потреба у вирішенні завдання щодо розгляду існуючих технологій охорони на предмет можливості їх застосування у певних умовах і необхідності вдосконалення або розробки нових. Цьому присвячена доволі велика кількість наукових досліджень. Для вирішення цього завдання використовуються різні підходи та методи, які потребують узагальнення та систематизації з метою вдосконалення методологічних основ проєктування технологій охорони підготовчих виробок.

Аналіз останніх досліджень і публікацій. Згідно з керівним документом [10], охорона виробок - це технологія проведення і заходи із забезпечення стійкості гірничих виробок, спосіб охорони - оптимальне за фактором гірничого тиску розташування гірничих виробок в шахті щодо очисних робіт, а засоби охорони - штучні споруди з боку очисних робіт для зниження зміщень порід. Тобто «охорона гірничих виробок» $є$ поєднуючим терміном, що містить способи і засоби їх охорони, а також додаткові заходи щодо забезпечення стійкості виробок. Їх застосування передбачає реалізацію сукупності прийомів і способів зміни стану порід навколо виробки з метою забезпечення ії стійкості. Тому технологічні процеси реалізації способів та засобів охорони можна називати технологіями охорони виробок.

Вибору технологій охорони гірничих виробок для певних умов присвячено декілька робіт, у тому числі керівних документів. Відповідно до них визначаються напрями пошуку та параметри прийнятних інженерних рішень щодо підтримання виробок. Стандарт СОУ 10.1.00185790.011:2007 [10] установлює вибір кріплення, способів і засобів охорони підготовчих виробок на глибинах до 1500 м під час проєктування. будівництва, експлуатації і реконструкції шахт, які розроблюють пологі вугільні пласти. Цей документ $\epsilon$ обов'язковим для розробників і виконавців проєктів та паспортів виїмкових дільниць. У ньому наведено перелік засобів кріплення підготовчих виробок, способів та засобів їх охорони, а також методику розрахунку зміщень порід у виробках з цими заходами. У цьому документі наведено регламентовані технології охорони. Але не завжди ці технології дозволяють гарантувати ефективну та безпечну охорону виробок, оскільки умови відпрацьовування вугільних пластів ускладнюються, i разом 3 ними мають змінюватися або вдосконалюватись технології. Таким чином, стандартом обмежена можливість розгляду інноваційних рішень, які можуть бути більш ефективними. До затвердження стандарту СОУ 10.1.00185790.011:2007 існував інший документ [11], спрямованість якого та призначення були такими ж як у наступника. 
Методика ІГС ім. О.О. Скочинського [12] призначена для вибору способів охорони підготовчих виробок під час розробки проєктів вугільних шахт на глибоких горизонтах для виймання пологих пластів тонких та середньої потужності. Для вибору заходів забезпечення безремонтного стану підготовчих виробок як критерію запропонована величина деформацій контуру виробки. Розглядається обмежена кількість способів та засобів охорони, а саме: проведення штреків під виробленим простором (польова підготовка); проведення пластової виробки у масиві, позаду лави та вприсічку до виробленого простору, вузьким або широким ходом, збільшеним перетином із застосуванням кріплень підвищеної піддатливості, з бурінням свердловин по пласту вздовж виробки; з охороною у системах «масив - масив», «масив - цілик», «масив - бутова смуга», «бутова смуга - бутова смуга». Для вибору способів і засобів охорони було рекомендовано методологічний підхід у роботах наукового колективу кафедри РРКК ДонНТУ $[13,14]$. В основу підходу покладено поетапний, консеквентний пошук існуючих або нових технічних рішень щодо охорони підготовчих виробок, їх систематизація, інтеграція й узагальнення, а також визначення витрат на реалізацію. Але у цій методиці порівняння способів охорони за економічними та технологічними критеріями поєднане спільними блоками. Тому, згідно 3 методикою, економічного обгрунтування потребували технології, які були визнані технологічно недоцільними. Крім того, методикою не визначено на якому етапі визначається раціональна технологія охорони виробки. Тому цю методику не можна вважати завершеною.

Метою статті $є$ вдосконалення методики вибору технологій охорони підготовчих виробок.

Викладення матеріалу та результати. Пропонована методика вибору технологій охорони підготовчих виробок грунтується на циклічному алгоритмі, блок-схема якого наведена на рисунку 1 . Цей алгоритм складається 3 блоків аналізу та перебору параметрів можливих технологічних рішень 3 їх економічним порівнянням на проміжних етапах для отримання у підсумку менш витратних технологій охорони і визначення серед них раціонального варіанта. На початку алгоритму здійснюється ретельний збір даних про гірничо-технічні та гірничо-геологічні умови, розглядається досвід охорони подібних виробок. Після того, як були зібрані необхідні дані, здійснюється поетапний вибір технології охорони.

На першому етапі вибирається місце розташування виробки щодо пласта та меж виробленого простору. На цьому ж етапі обгрунтовується необхідність розміщення виробки відносно очисного вибою (польова, в масиві вугілля, між виробленим простором і масивом, між виробленими просторами тощо).

Після вибору варіанта розташування виробки виконується контроль (спостереження та перевірка) їі експлуатаційного стану розрахунково, лабораторними або натурними методами. Якщо результати контролю вказують на те, що експлуатаційний стан забезпечується, визначаються витрати на реалізацію технології охорони з поточним варіантом розташування виробки. Потім здійснюється розгляд наступного варіанта розташування 3 визначенням витрат за позитивного контролю експлуатаційного стану, які порівнюються 3 попереднім варіантом. 3 них обирається менш витратний. Далі цикл повторюється. 3 декількох варіантів розташування виробки визначається раціональний з виразу

$$
B_{i}=\min \left(B_{i 1} ; B_{i 2} ; \ldots ; B_{i \mathrm{n}}\right),
$$

де $B_{i}$ - витрати на реалізацію раціональної технології охорони з ефективним розташуванням виробки, грн; $i 1 \ldots$ in - відомі варіанти розташування виробки, за яких забезпечується ії експлуатаційний стан.

Якщо за певних варіантів розташування виробки неможливо забезпечити експлуатаційний стан, то слід перейти до циклу «Вибір способів охорони з впливом на масив», де розглядаються можливі способи за поточного розташування. У цьому циклі здійснюється підбір відомих способів охорони та шляхів їх реалізації. Відсутність шляхів реалізації не означає завершення алгоритму, оскільки може розглядатися умова визначення доцільності розробки нових шляхів реалізації відомого способу охорони або перехід до блоку щодо визначення доцільності розробки нового способу охорони або удосконалення існуючого. Варто зазначити, що розробка нового способу на порядок складніша за розробку шляхів реалізації відомого та вимагає набагато більших затрат часу, праці й застосування доволі складних наукомістких операцій. Але, як перше, так і друге рішення приймаються на основі аналізу недоліків та переваг відомих способів. Розглядається можливість поєднання переваг в одній або кількох комбінаціях та оцінюється доцільність реалізації інновації. У першому та другому випадках за циклом здійснюється визначення параметрів, контроль експлуатаційного стану виробки за відповідної комбінації способу зі шляхом його реалізації і визначення витрат при позитивному контролі. Ці цикли можуть бути будь-коли зупинені, якщо буде знайдено новий шлях реалізації відомого способу, вдосконалено відомий або розроблено новий, що дозволить забезпечити експлуатаційний стан виробки з визначеними витратами.

Під час розгляду способів охорони 3 можливими шляхами їх реалізації здійснюється вибір раціональних варіантів за виразами:

$$
\begin{aligned}
& B_{j}=\min \left(B_{j 1} ; B_{j 2} ; \ldots ; B_{j \mathrm{k}}\right) ; \\
& B_{t}=\min \left(B_{t 1} ; B_{t 2} ; \ldots ; B_{t \mathrm{~m}}\right),
\end{aligned}
$$

де $B_{j}$ та $B_{t}$ - витрати на реалізацію раціональних способів охорони відомого та нового (вдосконаленого) відповідно, грн; $j 1 \ldots j \mathrm{k}$ та $t 1 \ldots t \mathrm{~m}$ - відповідно відомі та нові (вдосконалені) способи охорони виробки, за яких забезпечується її експлуатаційний стан. 


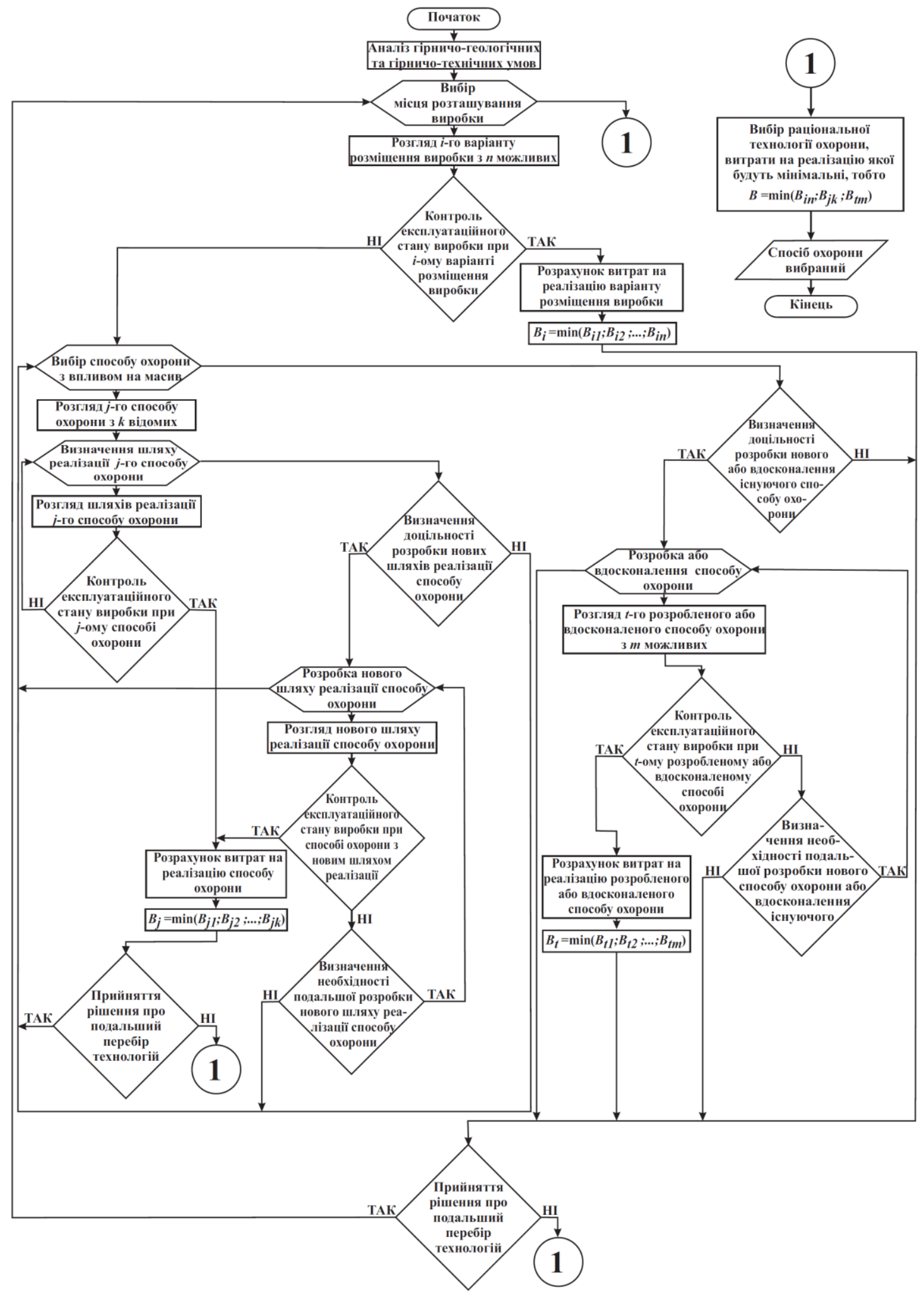

Рис. 1. Блок-схема для вибору технології охорони виробки

Якщо під час поетапного виконання алгоритму з визначеним розміщенням виробки не знайдено доцільного варіанта охорони, то відбувається повернення до блоку «Вибір місця розташування виробки» 3 подальшим аналізом альтернативного варіанта розташування і повторенням для цього варіанту всього алгоритму з вибору способу та шляхів його реалізації. 
У будь-якому випадку алгоритм завершується вибором раціональної технології, за якої забезпечується експлуатаційний стан виробки за рахунок вибраного розташування та способу охорони. Для цього використовується вираз

$$
B=\min \left(B_{i \mathrm{n}} ; B_{j \mathrm{k}} ; B_{t \mathrm{~m}}\right) .
$$

Розглянемо способи охорони з впливом на масив, що зазначені в одному з циклів алгоритму (рис. 1). Загальними ознаками способів і засобів управління стійкістю виробок вважаються [15]: їх взаємодія 3 масивом гірських порід навколо виробки (активні та пасивні); масштаб їх впливу на масив (регіональні та локальні); спрямованість їх впливу на стан масиву (зі зміною міцності порід та зі зміною напруженодеформованого стану (НДС) порід). Ці ознаки можна використати для розробки класифікації способів охорони підготовчих виробок, що передбачають вплив на навколишній масив. Пасивні та активні способи охорони поділяються на локальні та регіональні, які передбачають зміну НДС навколишніх порід або їх міцності. Регіональні способи реалізуються по всій довжині виробки та впливають на характер деформування iї контуру, локальні - реалізуються на обмежених ділянках навколишнього масиву для зменшення зміщень на окремих ділянках контуру. Розподіл заходів, які будуть реалізовуватись безпосередньо у виробці та навколо неї, пропонується здійснити за класифікаційною ознакою «за сутністю реалізації технологій охорони виробки», оскільки кожен із заходів на нижньому рівні передбачає виконання певного індивідуального набору технологічних операцій для досягнення загального результату - забезпечення стійкості виробки. Пропонована класифікація наведена на рисунку 2.

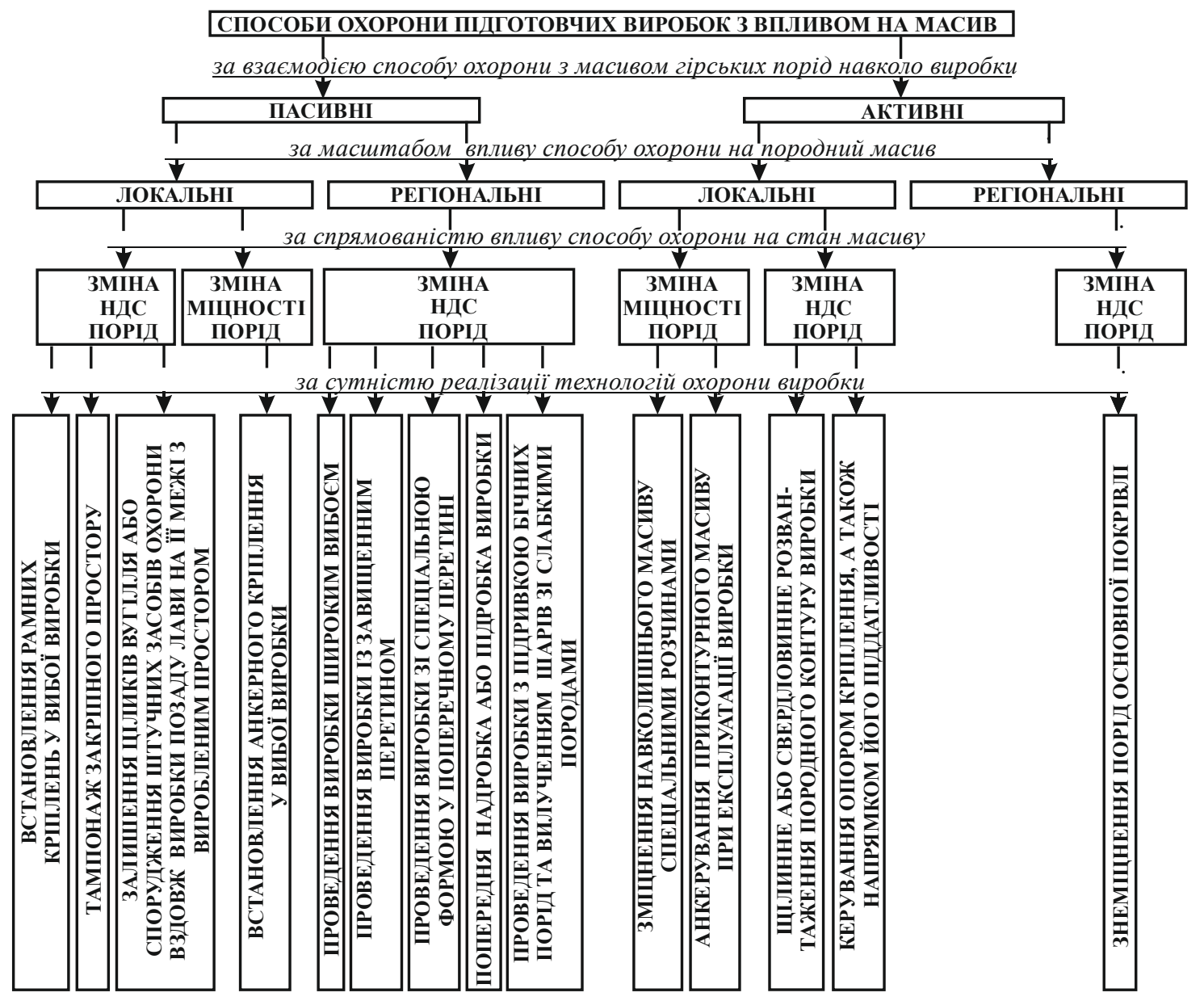

Рис. 2. Класифікаиія способів охорони підготовчих виробок, що передбачають вплив на навколишній масив

3 наведених способів охорони, що передбачають вплив на навколишній масив (рис. 2), тільки один $\epsilon$ обов'язковим, оскільки має реалізовуватись за визначених умов підтримання виробки. Так, в умовах підтримання виробок позаду лави, є обов'язковою наявність засобу охорони на межі з виробленим простором для утримання нависаючих порід, які втратили опору під час виймання корисної копалини. Цей захід належить до етапу експлуатації виробки та є невід’ємною частиною технологічної схеми ведення очисних робіт. 
Вибору засобу охорони та визначенню його прийнятних конструктивних особливостей має передувати їх аналіз (рис. 3). По-перше, розглядається основний матеріал охоронної конструкції, з якого вона може бути споруджена. По-друге, аналізуються можливі варіанти засобів охорони. Насамперед розглядаються засоби охорони, які рекомендуються нормативними документами. У подальшому в аналіз можуть бути додані інші засоби, які менш поширені, але показали свою ефективність у певних умовах. Якщо існуючі засоби не принесли бажаного результату, можна розглядати можливість їх вдосконалення або розробки нових за запропонованим алгоритмом. Для підвищення ефективності засобів охорони можуть бути запропоновані додаткові заходи. Особливо актуально це в умовах великих глибин та слабких бічних порід, що характерно для більшості вугільних шахт України.

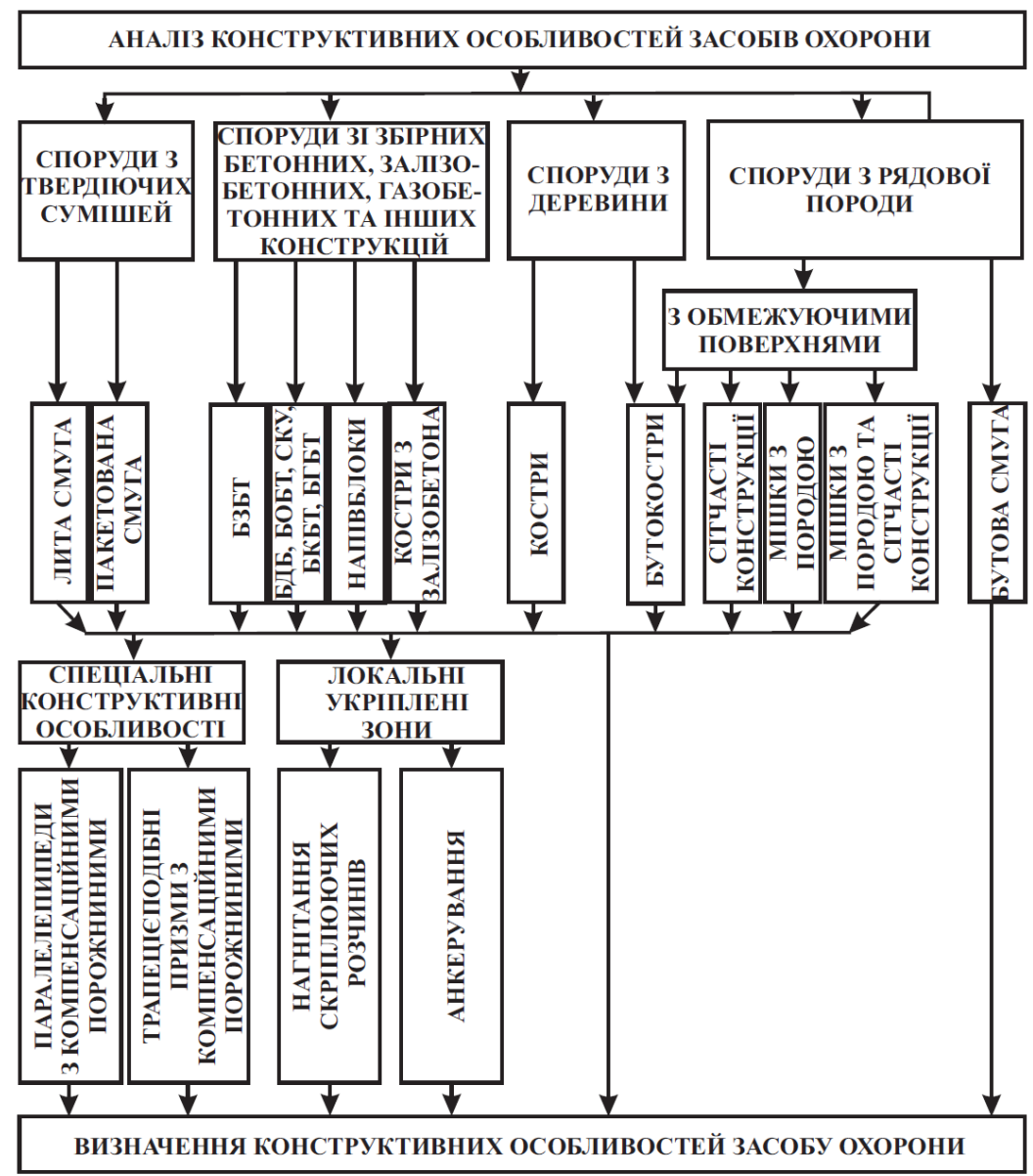

Рис. 3. Схема визначення конструктивних особливостей засобів охорони

В умовах Донбасу глибини ведення гірничих робіт не перевищують 1200 м, а частки слабких порід $\left(\sigma_{\text {ст }}<40 \mathrm{MПа}\right)$ та середньої міцності $\left(\sigma_{\text {ст }}=40 \div 70 \mathrm{MПа)} \mathrm{знаходяться} \mathrm{у} \mathrm{діапазонах,} \mathrm{відповідно,} 26,1 \div 40,1\right.$ та $44,6 \div 49,5 \%$ [16]. Для міцних порід $\left(\sigma_{\mathrm{cт}}=71 \div 100 \mathrm{MПа)} \mathrm{вона} \mathrm{змінюється} \mathrm{від} \mathrm{14,7} \mathrm{до} \mathrm{20,7} \mathrm{\% .} \mathrm{Найбільша}\right.$ кількість глибоких шахт експлуатується у Донецько-Макіївському, Покровському, Лисичанському, Алмазно-Мар'ївському та Чистяково-Сніжнянському вугленосних районах (рис. 4). Шахтний фонд більшості вугленосних районів (Донецько-Макіївського, Центрального, Амвросіївського, ЧистяковоСніжнянського, Луганського, Краснодонського, Оріхівського, Боково-Хрустальського, ДолжанськоРовенецького) - це старі шахти, які зношені, вимагають реконструкції та відновлення.

3 огляду на щільність запасів вугілля та його марочний склад, перспективними районами є: Петриківський, Новомосковський, Павлоградсько-Петропавлівський, Лозовський, Південно-Донбаський, Лисичанський, Покровський та Північний Донбас (Старобільська площа) [17] (рис. 4). Ці райони представлені вугленосними світами, для яких характерне залягання пологих вугільних пластів робочою потужністю від 0,6 до 2,5 м у слабких бічних породах.

Засоби охорони мають ретельно розглядатися на предмет їх можливості застосування в умовах слабких бічних порід. Для порід покрівлі вимоги менш жорсткі, ніж для підошви, оскільки стійкість охоронних споруд залежить від міцності підстилаючих порід. Кількість засобів охорони, які без додаткових заходів можуть використовуватися в умовах слабких порід підошви, обмежена та вони не 
завжди дозволяють забезпечити безремонтний стан виробки, що охороняється. Тоді розглядається можливість використання заходів, які передбачають створення спеціальних охоронних конструкцій або укріплення підстилаючих порід для перерозподілу й спрямування напружень в породному масиві у напрямку від виробки.

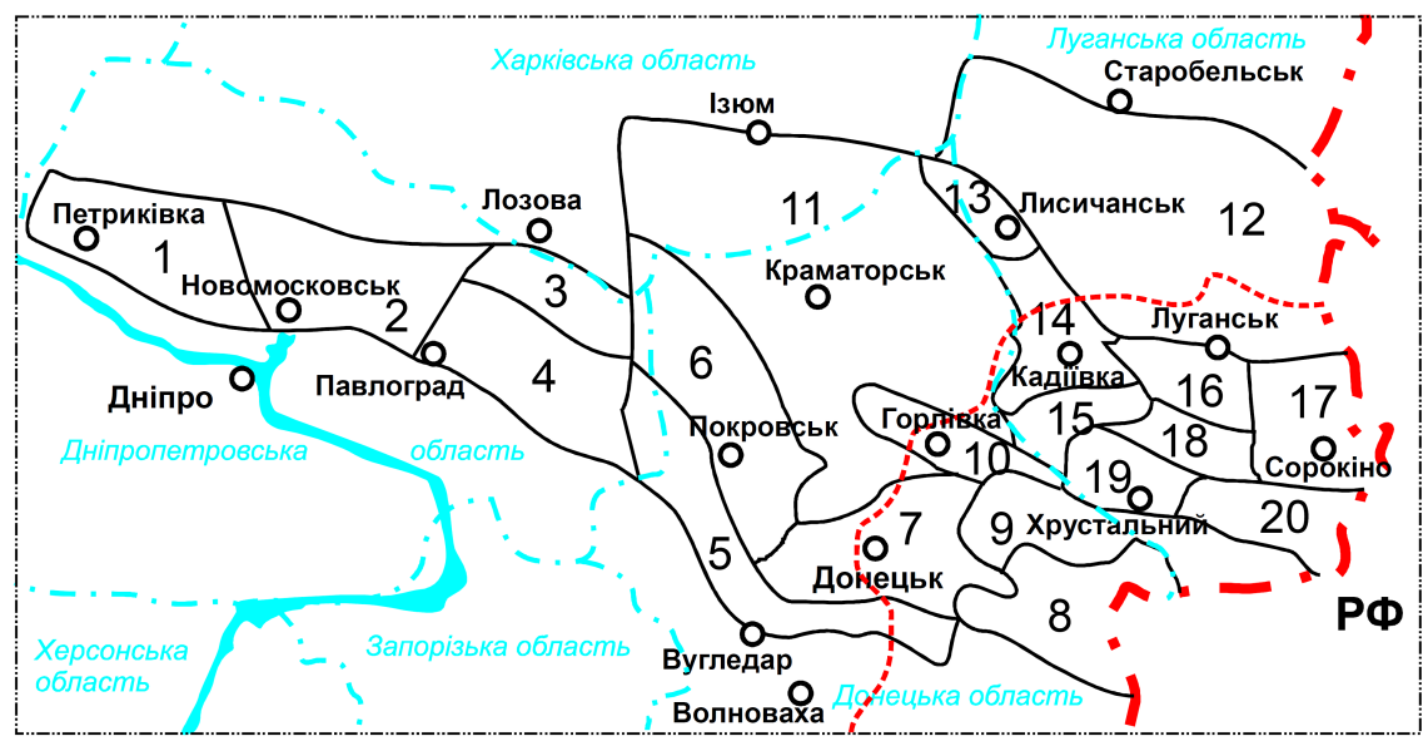

Рис. 4. Вугленосні райони Донецького басейну на території України

(1 - Петриківський, 2 - Новомосковський, 3 - Лозовський, 4 - Павлоградсько-Петропавлівський, 5 - Південно-Донбаський, 6-Покровський, 7 - Донеиько-Макївський, 8-Амвросївський, 9 - Чистяково-Сніжнянський, 10 - Центральний, 11 - Північно-Західна околиия Донбасу, 12 - Північний Донбас, 13 - Лисичанський, 14 - Алмазно-Мар'ївський, 15 - Селезнівський, 16 - Луганський, 17 - Краснодонський, 18 - Оріхівський, 19 - Боково-Хрустальський, 20 - Долюансько-Ровенецький)

Для мінімізації витрат на охорону виробок перевагу необхідно віддавати засобам охорони, що передбачають використання рядової породи від проведення та ремонту гірничих виробок без ії попередньої підготовки, й тим, які забезпечують високий рівень механізації робіт і високі темпи спорудження (якщо у цьому є потреба). Висока несуча здатність і незначна піддатливість засобів з рядової породи забезпечується створенням конструкцій із сипкого породного матеріалу й обмежуючих поверхонь. Їх економічні переваги зменшуються через збільшення витрат на транспортування породи до місця спорудження з віддалених прохідницьких вибоїв, місць проведення ремонтів або поверхні.

Для кожної технології охорони важливим є правильне визначення їх параметрів, оскільки від цього залежить технологічна та економічна ефективність. Для більшості існуючих технологій методики розрахунку параметрів у певних гірничо-геологічних та гірничо-технічних умовах відомі. Але 3 ускладненням гірничо-геологічних умов, ці технології зі своїми базовими параметрами не відповідають вимогам, які до них пред'являються, потребують вдосконалення або розширення областей використання впровадженням додаткових заходів з обов'язковим контролем експлуатаційного стану виробок під час іх застосування. Для цього може бути використана вдосконалена методика.

Висновки та перспективи подальших досліджень. За результатами проведених досліджень вдосконалено методику вибору технологій охорони підготовчих виробок, яка передбачає поетапний розгляд заходів щодо забезпечення експлуатаційного стану виробки та їх економічне порівняння. У ній використано новий підхід стосовно пошуку доцільних технічних рішень щодо підтримання виробки на будь-якому етапі іiі «життєвого циклу»: проєктування, проведення або експлуатації. Запропоновано класифікацію способів охорони підготовчих виробок, що передбачають вплив на навколишній масив, та рекомендації щодо визначення конструктивних особливостей засобів охорони. Вони можуть бути використані у запропонованій методиці для пошуку ефективного та ресурсозберігаючого рішення.

Отримані результати дозволяють перейти до наступного етапу - перевірки відповідності області застосування та уточнення параметрів існуючих технологій охорони підготовчих виробок до гірничогеологічних умов, що ускладнюються. Зокрема, планується приділити окрему увагу охороні підготовчих виробок в умовах слабких бічних порід, що характерні для перспективних вугленосних районів Донбасу. 
Список використаної літератури:

1. Presplitting Blasting the Roof Strata to Control Large Deformation in the Deep Mine Roadway / H.Chaowen, Y.Xiaojie, H.Ruifeng, M.Xingen // Advances in Civil Engineering. - 2020. - 15 p. DOI: https://doi.org/10.1155/2020/8886991.

2. Гапєєв C.M. Моделювання і прогноз геомеханічних процесів у виробках глибоких шахт : автореф. дис. на здобуття наук. ступеня д.т.н. : спец. 05.15.09 / C.M. Гапєєв. - НГУ. - Дніпропетровськ, 2014.

3. Failure Mechanism for Surrounding Rock of Deep Circular Roadway in Coal Mine Based on Mining-Induced Plastic Zone / Y.Yue, W.Weijun, L.Shuqing, Z.Yongjian // Advances in Civil Engineering. - 2018. - 14 p. DOI: https://doi.org/10.1155/2018/1835381.

4. Zhibiao G. Failure mechanism and supporting measures for large deformation of Tertiary deep soft rock / G.Zhibiao, W.Jiong, Z.Yuelin // International Journal of Mining Science and Technology. - 2015. - Vol. 25, Issue 1. P. 121-126. DOI: https://doi.org/10.1016/j.ijmst.2014.11.002.

5. Халимендик Ю.М. Применение крепи в слабых слоистых породах угольных шахт / Ю.М. Халимендик // Уголь Украины. - 2015. - № 3-4. - С. 20-25.

6. Kang H. Support technologies for deep and complex roadways in underground coal mines: a review / H.Kang // International Journal of Coal Science and Technology. - 2014. - № 1. - P. 261-277. DOI: https://doi.org/10.1007/s40789-014-0043-0.

7. Gob-Side Entry Retained with Soft Roof, Floor, and Seam in Thin Coal Seams: A Case Study / Z.Tian, Z.Zhang, M.Deng et.al. // Sustainability. - 2020. - Vol. 12, Issue 3. DOI: https://doi.org/10.3390/su12031197.

8. Ma Z. Key Technologies and Application Test of an Innovative Noncoal Pillar Mining Approach: A Case Study / Z.Ma, J.Wang, M.He et al. // Energies. - 2018. - Vol. 11, Issue 10. DOI: https://doi.org/10.3390/en11102853.

9. A study of the mechanical structure of the direct roof during the whole process of non-pillar gob-side entry retaining by roof cutting. / X.Liu, X.Hua, P.Yang, Z.Huang // Energy Exploration \& Exploitation. - 2020. - Vol. 3, Issue 5. P. 1706-1724. DOI: $10.1177 / 0144598720947470$.

10. Підготовчі виробки на пологих пластах. Вибір кріплення, способів і засобів охорони : СОУ 10.1.00185790.011:2007. - К. : Мінвуглепром України, 2007. - 113 с.

11. Указания по рациональному расположению, охране поддержанию горных выработок на угольных шахтах СССР. - Л. : ВНИМИ, 1986. - 222 с.

12. Методика выбора способов охраны подготовительных выработок от горного давления глубоких шахт. М. : МУП СССР, АН СССР, ИГД им. А.А. Скочинского, 1972. -27 с.

13. Новый подход к методике выбора способов охраны выработок глубоких шахт / Н.Н. Касьян, С.Г. Негрей, В.Н. Мокриенко, А.Л. Касьяненко // Вісті Донецького гірничого інституту. - 2012. - № 1. - С. 165-172.

14. Мокриенко B.Н. Новый подход к методике выбора способов охраны выработок глубоких шахт / В.Н. Мокриенко, А.Л. Касьяненко // Наукові праці УкрНДМІ НАН України. - 2012. - № 10. - С. 362-386.

15. Литвинский Г.Г. Эффективные способы предотвращения пучения пород в шахтах / Г.Г. Литвинский, Г.В. Бабиюк, А.В. Быков - М. : ЦНИЭИуголь, ЦБНТИ Минуглепрома УССР, 1985. - 48 с.

16. Кошелев К.В. Охрана и ремонт горных выработок / К.В. Кошелев, Ю.А. Петренко, А.О. Новиков. - М. : Недра, 1990. $-218 \mathrm{c}$.

17. Problems of mining the prospective coal-bearing areas in Donbas / S.Nehrii, T.Nehrii, L.Bachurin, H.Piskurska // E3S Web Conf. Ukrainian School of Mining Engineering. - 2019. - Vol. 123. DOI: https://doi.org/10.1051/e3sconf/201912301011.

\section{References:}

1. Chaowen, H., Xiaojie, Y., Ruifeng, H. and Xingen, M. (2020), «Presplitting Blasting the Roof Strata to Control Large Deformation in the Deep Mine Roadway», Advances in Civil Engineering, 15 p., doi: https://doi.org/10.1155/2020/8886991.

2. Gapjejev, S.M. (2014), «Modeljuvannja i prognoz geomehanichnyh procesiv u vyrobkah glybokyh shaht», Abstract of D.Sc. dissertation, spec. 05.15.09, NGU, Dnipropetrovs'k.

3. Yue, Y., Weijun, W., Shuqing, L. and Yongiian, Z. (2018), «Failure Mechanism for Surrounding Rock of Deep Circular Roadway in Coal Mine Based on Mining-Induced Plastic Zone», Advances in Civil Engineering, 14 p., doi: https://doi.org/10.1155/2018/1835381.

4. Guo, Z., Wang, J. and Zhang, Y. (2015), «Failure mechanism and supporting measures for large deformation of Tertiary deep soft rock», International Journal of Mining Science and Technology, Vol. 25, Issue 1, pp. 121-126, doi: https://doi.org/10.1016/j.ijmst.2014.11.002.

5. Khalimendik, Yu.M. (2015), «Primenenie krepi v slabykh sloistykh porodakh ugol'nykh shakht», Ugol' Ukrainy, No. 3-4, pp. 20-25.

6. Kang, H. (2014), «Support technologies for deep and complex roadways in underground coal mines: a review», International Journal of Coal Science and Technology, No. 1, pp. 261-277, doi: https://doi.org/10.1007/s40789-0140043-0.

7. Tian, Z., Zhang, Z., Deng, M. et al. (2020), «Gob-Side Entry Retained with Soft Roof, Floor, and Seam in Thin Coal Seams: A Case Study», Sustainability, Vol. 12, Issue 3, doi: https://doi.org/10.3390/su12031197.

8. Ma, Z., Wang, J., He, M. et al. (2018), «Technologies and Application Test of an Innovative Noncoal Pillar Mining Approach: A Case Study», Energies, Vol. 11, Issue 10, doi: https://doi.org/10.3390/en11102853. 
9. Liu, X., Hua, X., Yang, P. and Huang, Z. (2020), «A study of the mechanical structure of the direct roof during the whole process of non-pillar gob-side entry retaining by roof cutting», Energy Exploration \& Exploitation, Vol. 38, Issue 5, pp. 1706-1724, doi: 10.1177/0144598720947470.

10. Minvugleprom Ukrai'ny (2007), SOU 10.1.00185790.011:2007: Pidgotovchi vyrobky na pologyh plastah. Vybir kriplennja, sposobiv i zasobiv ohorony, K., 113 p.

11. Ukazaniya po ratsional'nomu raspolozheniyu, okhrane podderzhaniyu gornykh vyrabotok na ugol'nykh shakhtakh SSSR (1986), VNIMI, L., 222 p.

12. Metodika vybora sposobov okhrany podgotovitel'nykh vyrabotok ot gornogo davleniya glubokikh shakht (1972), MUP SSSR, AN SSSR, IGD im. A.A. Skochinskogo, M., 27 p.

13. Kas'yan, N.N., Negrei, S.G., Mokrienko, V.N. and Kas'yanenko, A.L. (2012), «Novyi podkhod k metodike vybora sposobov okhrany vyrabotok glubokikh shakht», Visti Donec'kogo girnychogo instytutu, No. 1, pp. 165-172.

14. Mokrienko, V.N. and Kas'yanenko, A.L. (2012), «Novyi podkhod k metodike vybora sposobov okhrany vyrabotok glubokikh shakht», Naukovi praci UkrNDMI NAN Ukrai'ny, No. 10, pp. 362-386.

15. Litvinskii, G.G., Babiyuk, G.V. and Bykov, A.V. (1985), Effektivnye sposoby predotvrashcheniya pucheniya porod v shakhtakh, TsNIEIugol', TsBNTI Minugleproma USSR, M., 48 p.

16. Koshelev, K.V., Petrenko, Yu.A. and Novikov, A.O. (1990), Okhrana i remont gornykh vyrabotok, Nedra, M., 218 p.

17. Nehrii, S., Nehrii, T., Bachurin, L. and Piskurska, H. (2019), «Problems of mining the prospective coal-bearing areas in Donbas», E3S Web Conf. Ukrainian School of Mining Engineering, Vol. 123, doi: https://doi.org/10.1051/e3sconf/201912301011.

Негрій Сергій Григорович - кандидат технічних наук, доцент кафедри розробки родовищ корисних копалин ДВНЗ «Донецький національний технічний університет».

https://orcid.org/0000-0002-3195-8401.

Наукові інтереси:

- розробка родовищ корисних копалин;

вугілля.

E-mail: serhii.nehrii@donntu.edu.ua.

Стаття надійшла до редакції 09.04.2021. 